\title{
OS PERCALÇOS DA PROPRIEDADE CAFEEIRA: A TRANSFORMAÇÃO DOS DIREITOS DE PROPRIEDADE NA FORMAÇÃO E NA REPRODUÇÃO DAS FAZENDAS DE CAFÉ EM VALLEÇA (PROVÍNCIA DO RIO DE JANEIRO, 1850-1888)
}

\author{
THE SETBACKS OF THE COFFEE PROPERTY: THE \\ TRANSFORMATION OF PROPERTY RIGHTS IN THE FORMATION \\ AND REPRODUCTION OF THE COFFEE FARMS IN VALENÇA \\ (PROVINCE OF RIO DE JANEIRO, 1850-1888)
}

Felipe de Melo Alvarenga ${ }^{1}$

\begin{abstract}
RESUMO: O objetivo do presente artigo é analisar a transformação dos direitos de propriedade no processo de formação e de reprodução das fazendas de café no município de Valença após a promulgação da Lei de Terras de 1850. Para isso, analisaremos um estudo de caso envolvendo um megaproprietário, aquele fazendeiro que possuía mais de 100 cativos e diversas propriedades rurais segundo a classificação de Ricardo Salles, e uma comunidade de posseiros que foi incorporada à fazenda na condição de agregados, no momento de transformação da mata virgem em cafezais. Avaliaremos as principais mudanças ocorridas na relação entre o fazendeiro e os agregados, principalmente quando o senhor decidiu expropriá-los no mesmo momento em que estabelecia contratos de parceria com imigrantes estrangeiros. Acreditamos que o caso analisado pode nos revelar importantes conclusões para entendermos como foram formadas as grandes fazendas de café, partindo da perspectiva analítica que preza pelo entendimento dos conflitos de direitos de propriedade no Brasil do século XIX.
\end{abstract}

PALAVRAS-CHAVE: direitos de propriedade; fazenda cafeeira; agregados; fazendeiros.

ABSTRACT: The purpose of this paper is to analyze the transformation of property rights in the process of formation and reproduction of coffee farms in Valença in the

\footnotetext{
* O artigo é resultado de uma parte modificada do capítulo 3, apresentado em minha dissertação de mestrado. Ver: ALVARENGA, Felipe de Melo. De Terras Indígenas à Princesa da Serra Fluminense: o processo de realização da propriedade cafeeira em Valença (Província do Rio de Janeiro, Século XIX). Jundiaí [SP]: Paco Editorial, 2019. Esta pesquisa contou com o financiamento da Fundação de Amparo à Pesquisa do Estado de São Paulo (FAPESP) no formato de bolsa de mestrado no país, constante do processo 2017/18127-8.

${ }^{1}$ Doutorando em História pela Universidade Federal Fluminense (UFF), mestre em História Social pela Universidade Estadual de Campinas (UNICAMP) e bacharel e licenciado em História pela Universidade Federal do Rio de Janeiro (UFRJ). E-mail para contato: f.m.alvarenga@hotmail.com.
} 
period following the enactment of the Land Law of 1850. To this end, we will analyze a case study involving a "mega-owner", that farmer who owned more than 100 captives and several rural properties according to the classification of Ricardo Salles, and a community of "posseiros" that were incorporated into the farm as "agregados" at the time of transformation of virgin forest into coffee plantations. We will evaluate the main changes in the relationship between the farmer and the "agregados", especially when the farmer decided to expropriate them at the same time as he steadied into partnership agreements with foreign immigrants. We believe that the case analyzed may reveal important conclusions for us to understand how large coffee farms were formed, starting from the analytical perspective that values the understanding of conflicts over property rights in 19th century Brazil.

KEYWORDS: property rights; coffee farm; agregados; farmers.

\title{
Introdução
}

\begin{abstract}
Eram pessoas da casa. Difícil explicar-se essa situação - viver no seio de uma família, de que não é membro, nem hóspede. A mais de um, perguntado se era hóspede, respondia negativamente. Então, é parente? Não, sou pessoa de casa. Ficavam nisso. Era uma explicação que, afinal, nada explicava (ANDRADE, 1989: 208).
\end{abstract}

Manoel Eloy dos Santos Andrade (1872-1948) foi um memorialista que dedicou anos de pesquisa sobre a região do Vale do Paraíba Fluminense. Escreveu seu livro de memórias nas décadas de 1920 e 1930 a partir dos relatos contados por seu pai e por outros indivíduos que possuíam fortes vínculos com a aristocracia rural local, além de suas próprias lembranças pessoais acerca dos últimos anos da monarquia (ANDRADE, 1989: 11-15).

$\mathrm{O}$ autor fez referência a diversos atores históricos que viveram o contexto da produção cafeeira no Vale no século XIX. Dentre estes, Manoel Andrade apresentou a figura do "encostado": um personagem bastante singular identificado no interior das fazendas de café. Para ele, os encostados eram parentes, próximos ou afastados, compadres ou vizinhos empobrecidos, que haviam perdido suas terras e que viviam nas fazendas como moradores de favor. Nelas, ficavam meses e anos, em intimidade com os proprietários, chegando a parecer, aos olhos de vizinhos e transeuntes, membros da família, isto é, "pessoas da casa" (ANDRADE, 1989: 208-210). O memorialista criou, inclusive, uma analogia com o método utilizado por Sherazade (as estorinhas contadas toda noite pela rainha para sobreviver e poupar sua vida) no famoso 
livro As Mil e Uma Noites, no qual estes dependentes contornavam diversas situações para reproduzir o seu "encosto". Conquistando "a amizade das crianças, ensinando-lhes a soltar papagaios" ou prontificando-se "a trabalhar no pomar", sem deixar de trazer alguns presentes e regalias à família hospedeira, estes encostados mobilizavam várias estratégias para permanecerem por ali (ANDRADE, 1989: 208-210).

Contudo, acreditamos que esta caracterização é bastante pejorativa. A visão particular de Manoel Andrade reforçou o estereótipo sobre a vida de alguns homens e mulheres que viveram durante o período escravista lutando para conquistar um acesso estável à terra, a despeito de não possuírem o título da propriedade (MOTTA, 1998; MATTOS, 2009). Esta era também a visão de mundo da elite agrária valenciana. Ao caracterizar os de baixo como "encostados", o memorialista desqualificou a agência destes indivíduos, reiterando uma desclassificação social internalizada no discurso de quem buscava braços para trabalhar na produção agrícola comercial (MELLO E SOUZA, 2004; LOURENÇO, 2001: 99). Tal discurso estereotipado foi atualizado, inclusive, no período pós-abolição por parte dos fazendeiros que criticavam a escassez, a vadiagem e a instabilidade do trabalho oferecido pelos trabalhadores nacionais nas fazendas cafeeiras do Sudeste (NAXARA, 1998; AZEVEDO, 2004; TESSARI, 2012: 139-154).

$\mathrm{Na}$ verdade, a violenta reprodução do monopólio da terra e as dificuldades de inserção econômica de homens e mulheres livres e pobres em uma sociedade escravista compeliram alguns indivíduos a se agregarem a um senhor para conseguir sobreviver, mesmo que isto significasse ingressar numa espécie de dominação social pessoalizada (FRANCO, 1997: 100). A relação de agregação era caracterizada por uma concessão de terras ao agregado naqueles terrenos excedentes da fazenda, onde aquele pudesse construir uma casa para morada, com possibilidade de cultivar no solo adjacente (SAMARA, 1977; 2005: 28-29).

Longe de não terem "razão de ser", muitos agregados foram bastante utilizados em atividades fundamentais na formação da fazenda cafeeira: eles 
eram os responsáveis pelos serviços mais arriscados, como a derrubada das matas e a consequente preparação das terras para dar início aos serviços da produção agrícola comercial tocada, principalmente, pela mão-de-obra escrava (MUNIZ, 1979; TESSARI, 2012). Com a estabilização das fazendas, muitos conseguiram reproduzir seu acesso à terra ao longo do tempo, o que lhes possibilitou uma autonomia relativa em relação ao proprietário. Em alguns casos, os agregados até chegaram a questionar se parte das terras nas quais eles trabalhavam eram realmente do exclusivo domínio do fazendeiro.

Desse modo, o cotidiano de relacionamento na propriedade cafeeira era um tanto imprevisto: de um lado, temos o agregado lutando para desenvolver seu espaço de autonomia dentro da fazenda e, de outro, temos o senhor buscando limitá-lo, controlando as ações daquele. Esta dinâmica é caracterizada pelo paternalismo que definia as relações de poder no mundo rural do Brasil oitocentista: o movimento de alargamento e constrição da autonomia dos agregados era determinado por um campo de forças que era tensionado pela polarização de interesses antagônicos - o do senhor e o do agregado (GENOVESE, 1998: 19-190; THOMPSON, 1998: 25-85).

Em razão disso, imbuídos de uma paciência beneditina, aqueles "encostados" perseguiam objetivos próprios, agindo por dentro da lógica senhorial, buscando induzir no senhor os interesses e os movimentos que interessavam a eles. Esta administração precária do cotidiano por parte destes dependentes em situação de vulnerabilidade nos revela as complexidades destas relações, que permitiam a conformação de um espaço imprevisível de diálogo, mediado por conflitos, numa espécie de economia de favores e concessões (CHALHOUB, 2003: 46-47). Isto é, uma "economia" que é atravessada por relações de força exercidas por agentes sociais em posições desiguais no campo (BOURDIEU, 2001).

Neste sentido, o objetivo deste artigo é analisar o processo de formação e de estabilização das fazendas de café partindo das contendas travadas pelos agregados que viviam nelas. Buscaremos identificar os conflitos em torno dos direitos de propriedade no interior da fazenda cafeeira no intuito de avaliar 
como estes agregados lutaram para garantir seus espaços de autonomia e manter suas margens de decisão e escolha em Valença, um dos municípios cafeeiros mais importantes do Vale do Paraíba no Oitocentos. Nossa proposta é avançar nas discussões sobre o contexto histórico posterior à promulgação da Lei de Terras de 1850, para compreender como se davam as relações entre aqueles proprietários que declararam seus terrenos nos Registros Paroquiais de Terras e os moradores que viviam dentro destas propriedades. O método de pesquisa consistiu em cotejar os nomes destes declarantes com processos cíveis e criminais envolvendo seus agregados - os não-declarantes -, logo após o registro dos anos de 1854 a 1857. Para os propósitos deste artigo, elegemos um caso - que produziu vasta documentação histórica encontrada nos arquivos envolvendo um megaproprietário, aquele fazendeiro que possuía mais de 100 cativos e diversas propriedades rurais segundo a classificação de Ricardo Salles (2008: 155) realizada para o município de Vassouras, que conflitou com uma comunidade de agregados no momento de formação de sua fazenda.

Tentaremos descortinar novas leituras e significados sobre o contexto pós-1850, buscando entender como os agentes sociais utilizaram diferentes artifícios para atingir seus objetivos. E isso é ainda mais perceptível na segunda metade do Oitocentos, momento em que a justiça local teve que lidar com relações sociais e formas costumeiras de acesso à terra, praticadas desde o início do século, e que continuavam sendo reproduzidas depois de 1850, apesar de uma Lei ter sido promulgada prevendo o contrário (MOTTA, 1998). Nesta direção, na interface entre a lei e a prática social, brechas foram abertas, o que permitiu a construção de estratégias que modificaram constantemente a realidade social (LEVI, 1992: 133-161).

Uma destas estratégias foi justamente mobilizar algumas denominações para caracterizar uma relação de propriedade: os termos podiam ser transformados a todo o momento, tanto pelos senhores quanto pelos próprios agregados, principalmente quando a contenda era encaminhada à justiça (MOURA, 1988). Estas mudanças eram bastante dinâmicas e revelavam o esforço dos proprietários em atribuir noções como "invasor" e "turbador" ao 
agregado, e o esforço deste que, por sua vez, lutava para ser reconhecido como um legítimo posseiro, confrontante do senhor (MOTTA, 1998: 205). Estavam em jogo estratégias proprietárias diferentes para defender direitos de propriedade na justiça, o que sinalizava um complexo uso de algumas categorias sociais que não devem, de maneira simplificada, congelar experiências humanas (THOMPSON, 1981).

Em visto disso, arriscaremos na tentativa de analisar a reconfiguração dos direitos de propriedade do agregado à luz das relações sociais construídas entre ele e o proprietário legal. Como Rosa Congost (2007) nos expressou, não devemos considerar seu direito à terra como uma carga/estorvo ou, para reiterar o termo do memorialista, como um "encosto" que impedia o pleno gozo da propriedade. A propriedade cafeeira foi o resultado acumulado do exercício de diversos direitos de propriedade, sejam eles protegidos ou desprotegidos pelo Estado (CONGOST, 2007: 18-19). Dentre estes direitos, estava o do agregado. A seguir, buscaremos compreender como a realização da propriedade cafeeira na cidade de Valença teve que lidar com estes direitos de propriedade exercidos pelos agregados que viviam no interior das fazendas de café.

Declarando fazendas, inventariando bens: o complexo cafeeiro do megaproprietário

No dia 28 de fevereiro de 1856, na freguesia de Nossa Senhora da Conceição do Paty do Alferes, no município de Vassouras, José Pereira de Almeida fez uma declaração de terras, dizendo ser morador na freguesia e senhor e possuidor da fazenda Ubá. ${ }^{2}$ A fazenda Ubá, juntamente com a fazenda Pau-Grande, foram os primeiros empreendimentos agrícolas formados no início do processo de ocupação das terras em Valença, na época em que José Rodrigues da Cruz iniciava os seus primeiros contatos com os índios Coroados no final do Setecentos (MACHADO, 2012; LEMOS, 2016; ALVARENGA, 2019).

\footnotetext{
2 APERJ: Livro 74 (1854-1858). Município de Vassouras: Freguesia Nossa Senhora da Conceição do Paty do Alferes. Registro 114, Folha 18.
} 
A fazenda Ubá possuía uma légua de testada e uma légua e meia de fundos ${ }^{3}$, confrontando com a família Ribeiro de Avellar e com a margem do Rio Paraíba (STEIN, 1990: 35-36; SILVA, 1984). Pertencia ao declarante por herança de seu pai, João Rodrigues Pereira de Almeida, o Barão de Ubá, conhecido comerciante de grosso trato estabelecido na praça mercantil do Rio de Janeiro e sobrinho de José Rodrigues da Cruz (FRAGOSO, 1998: 24).

No inventário do ano de 1860 de sua primeira esposa, Elisa Constança de Almeida, percebemos que a fazenda Ubá era o estabelecimento onde José Pereira de Almeida vivia com sua família (seus dois filhos, João e Joaquim Pereira de Almeida, e sua mulher). ${ }^{4}$ A declaração desta fazenda nos Registros Paroquiais representava a intenção proprietária de assegurar o poder sobre uma enorme unidade de produção que contava com uma luxuosa mobília e uma vastidão de terras. A Ubá era a sede de seu patrimônio rural no Vale do Paraíba; daí a necessidade de reafirmá-la e de fazê-la conhecida pelo Estado e pela comunidade de lavradores ao redor.

Esta fazenda foi primeiramente avaliada em meados de 1860 no valor total de 690 contos e 812 mil réis. Contava com 249 escravos, 2 sesmarias e meia de terras cultivadas no valor de 112:500\$000 réis e mais 2 sesmarias e meia, ainda em matas virgens, avaliadas em 150:000\$000 réis. Ou seja, havia muitas terras ainda incultas que representavam a possibilidade de reprodução das atividades produtivas em várias direções. Além disso, foram avaliados 30 mil pés de café em 6 contos de réis, complementados com a produção de açúcar

\footnotetext{
${ }^{3}$ Segundo Manoela Pedroza (2011), a testada seria o lado "da frente do quadrado de uma fazenda, ou seja, aquele considerado de entrada, quase sempre limítrofe com uma estrada, caminho, ou com a testada de outrem. A testada se opõe aos 'fundos', quase sempre não medidos" e a légua equivaleria a 6.500 metros ou 3.000 braças, sendo a "légua de sesmaria" uma medida itinerária antiga equivalente a, aproximadamente, 6.600 metros (PEDROZA, 2011: 268-271). De qualquer forma, apesar do esforço de aproximação e de atualização destas medidas agrárias para o observador contemporâneo, é preciso frisar que, no século XIX, elas eram bastante imprecisas e muitas delas feitas sem a devida comprovação competente dos agrimensores responsáveis pela demarcação judicial. Segundo Márcia Motta (1998), as complicações para se estabelecerem os limites precisos das fazendas estariam ligadas à dificuldade de delimitar, conjuntamente, o poder senhorial praticado e exercido no mundo rural oitocentista. Para um estudo de caso sobre estas medidas agrárias e as imprecisões contidas nas declarações de terras, ver Rosane Carvalho Messias (2003: 59-68).

${ }^{4}$ ETMP/IPHAN: Nome da parte 1: Elisa Constança de Almeida (Inventariada), Nome da parte 2: José Pereira de Almeida (Inventariante). Ação: Cível - Inventário. Ano do Processo: 1860. Comarca: Vassouras. Notação do Processo: 102668651007.
} 
e aguardente para fins de exportação; dois gêneros comerciais ainda bem cotados no mercado externo na segunda metade do século XIX. A valorização desta fazenda é concluída com as várias joias e pratarias pertencentes à falecida Elisa Constança de Almeida, comprovando o luxo que esta família conseguiu angariar ao longo do tempo. ${ }^{5}$

Ainda mais, o casal tinha uma fazenda denominada Salvaterra, no município de Niterói, contando com 1.430 braças de testada e 670 braças de fundos incorporadas da fazenda Carvalheza. A Salvaterra tinha, aproximadamente, 70 escravos e um expressivo número de animais, a saber: 84 bois de carro, 73 vacas, 58 bezerros, 33 burros, 25 carneiros, 2 porcas com leitões, 3 capados, entre outros bens. Parece que esta fazenda não se dedicava, estritamente, à produção comercial: afora a produção de algum açúcar e aguardente, a especialização da Salvaterra era a plantação de milho, feijão, mandioca e farinha, além da produção de carnes com o gado suíno e bovino identificado anteriormente. ${ }^{6}$

De mais a mais, foram inventariadas em 1861 várias propriedades urbanas existentes na Corte, nas principais ruas do centro do Rio de Janeiro, avaliadas na quantia de 320 contos e 700 mil réis. Casas térreas, lojas e chácaras completavam o patrimônio dessa família que também tinha na cidade a sua forma de ostentar a abastança que conseguiram acumular durante os anos. ${ }^{7}$ Neste ínterim, com uma fazenda-sede, uma fazenda-abastecedora e casas urbanas, José Pereira de Almeida poderia ser considerado um megaproprietário (SALLES, 2008: 155) visto que possuía, aproximadamente, 320 escravos contabilizados em seus estabelecimentos.

\footnotetext{
${ }^{5}$ Idem, p. 7-23.

${ }^{6}$ Ibidem, p. 30-40. Segundo Márcia Motta (1989), era comum a produção policultora nas "Bandas D'além", terras localizadas do outro lado da Baía da Guanabara, abarcando as zonas rurais dos atuais municípios de Niterói e São Gonçalo, principalmente depois da transferência da Corte portuguesa para a cidade do Rio de Janeiro em 1808. Segundo a autora, a região passou por intensas modificações neste contexto histórico. Uma delas foi a orientação da produção para o mercado interno, com dedicação para as atividades agropecuárias, para o abastecimento da cidade do Rio de Janeiro. Os arrendatários foram os personagens sociais mais representativos desta realidade, visto que eram eles que cultivavam no outro lado da Baía para atender a esta demanda interna.

${ }^{7}$ ETMP/IPHAN: Processo cível de Inventário (Elisa Constança de Almeida e José Pereira de Almeida), p. 45-45v; p. 52-58v.
} 
Além destes bens, alguns meses depois de declarar a fazenda Ubá em Vassouras, José Pereira de Almeida ${ }^{8}$ decidiu registrar mais uma propriedade, dessa vez no Distrito de Santa Tereza da Vila de Valença, em julho de $1856 .{ }^{9}$ Declarou que possuía outra fazenda denominada Casal, que se encontrava medida e demarcada, a qual abarcava nada menos que oito sesmarias! Era também uma herança legada por seu pai, o Barão de Ubá. Mas por que decidiu declarar esta fazenda tendo que se deslocar até a paróquia de Nossa Senhora da Glória de Valença para que o vigário a registrasse? Esta pergunta guiará nossa análise para compreendermos o que aconteceu nesta fazenda antes e depois de sua declaração nos Registros Paroquiais de Terras.

A fazenda Casal foi avaliada no inventário de Elisa Constança de Almeida em meados de fevereiro de 1864, a pedido do próprio José Pereira de Almeida. Curiosamente, nesta avaliação identificamos somente cinco sesmarias e não oito como constava na declaração da fazenda. A sesmaria Casal foi avaliada em 30:000\$000 réis; 2 sesmarias no "Abarracamento" foram avaliadas em 80:000\$000; e mais 2 sesmarias no "Posto Velho", a margem do Paraíba, foram avaliadas em 100:000\$000. A fazenda Casal tinha uma mobília mais humilde se comparada com o luxo da fazenda Ubá e alguns poucos animais. Isto porque foi notória sua especialização produtiva, relativamente recente, voltada para a produção cafeeira: foram avaliados 94 mil pés de café de 8 a 9 anos (18:800\$000); 54 mil pés de café de 6 a 7 anos (9:720\$000); e 136 mil pés de café de 16 a 19 anos (19:040\$000), o que superava a produção de café da fazenda Ubá. ${ }^{10}$

Ao declarar terras em dois dos municípios mais importantes do Vale do Paraíba fluminense, José Pereira de Almeida buscava se afirmar como grande

\footnotetext{
${ }^{8}$ José Pereira de Almeida foi listado enquanto fazendeiro na Freguesia de Nossa Senhora da Glória de Valença em 1848, 1849 e 1851 e na Freguesia de Santa Tereza (onde estava localizada a fazenda Casal) foi listado da mesma forma do ano de $1852 \mathrm{em}$ diante. Ver: Almanak Administrativo, Mercantil e Industrial da Corte e da Província do Rio de Janeiro. Rio de Janeiro: Laemmert, 1848-1860. Município de Valença. Disponível em: <www.crl.edu/brazil/almanak>. Acesso em: 19/01/19.

${ }^{9}$ APERJ: Livro 88 (1854-1857). Município de Valença: Freguesia Nossa Senhora da Glória. Registro 250, Folha 64.

${ }^{10}$ ETMP/IPHAN: Processo cível de Inventário (Elisa Constança de Almeida e José Pereira de Almeida), p. 66-76v.
} 
senhor de terras e homens mobilizando, para isso, o título de herdeiro do Barão de Ubá, homem que também possuiu enorme prestígio em Vassouras. Ambas as fazendas estavam localizadas em freguesias próximas, mas separadas pelo Rio Paraíba do Sul. Não foi à toa que identificamos "uma barca de passagem e seus pertences" e "uma canoa sem valor para ultrapassar o Rio Paraíba", com dois escravos barqueiros, e uma ponte que estava sendo consertada no caminho do Paraíba, na avaliação dos bens da fazenda Casal e Ubá. ${ }^{11}$ Isto sinalizava, provavelmente, a via de transporte fluvial entre os dois estabelecimentos; com o escoamento da produção para o porto do Rio de Janeiro assegurado pelas estradas do Comércio e da Polícia, igualmente próximas às duas fazendas (STEIN, 1990: 135-138). ${ }^{12}$ Logo, todo o seu patrimônio conformava um grande complexo cafeeiro, que poderia ser até interligado com outras propriedades rurais pertencentes aos seus amigos, conhecidos e familiares (FREIRE, 2014; PESSOA, 2018).

Surpreendentemente, o ano anterior à declaração das terras, em 1855, pareceu ser bastante agitado para José Pereira de Almeida, ao verificarmos que ele se envolveu em três processos de despejo encaminhados à Relação do Rio de Janeiro e em mais cinco processos de despejo que foram julgados no juízo municipal de Valença, todos abertos por sua autoria e interesse. Tratavam-se de conflitos envolvendo uma comunidade de agregados que morava nas beiradas da Fazenda Casal, no lugar denominado Mundo Novo.

O protocolo dos processos foi sempre o mesmo: José Pereira de Almeida alegou, no dia 26 de junho de 1855, que em uma de suas fazendas achavam-se alguns agregados que persistiam em habitar e cultivar as terras sem o seu consentimento. ${ }^{13} \mathrm{O}$ que chama a atenção é justamente o termo que

\footnotetext{
${ }^{11}$ Idem, p. 7-23; p. 66-76v.

12 Segundo Marquese e Tomich (2009), muitos destes megaproprietários fundaram várias fazendas contíguas, cada qual com sua sede (senzalas, terreiros, engenhos e tulhas) em vez de integrá-las num só latifúndio, para que não ocorressem longas caminhadas da senzala aos cafezais e a consequente perda desnecessária de tempo e de energia dos trabalhadores. Em nosso caso, a fundação "separada" das duas fazendas de José Pereira de Almeida foi consequência de um limite natural: o curso do Rio Paraíba do Sul.

${ }^{13}$ AMJERJ/CCPJ: Nome da parte 1: Jose Pereira d' Almeida, Nome da parte 2: José Barbosa. Ação: Cível - Despejo. Ano do Processo: 1855. Comarca: Valença. Caixa: 1712/A. Cód. Item: 17087. Tombo: 016296.
} 
especificava a relação construída entre os réus e o autor do processo: agregados que se meteram na fazenda sem o consentimento do senhor. Ao recorrermos à historiografia, percebemos que esta caracterização era um tanto contraditória; o que distinguia a figura do agregado da figura do posseiro era, justamente, "a permissão do dono para morar na terra e lavrá-la, o que vai formar entre eles, senhor e agregado", alguns vínculos de trabalho, sujeição clientelista e dominação social (SAMARA, 1977: 10-121).

Ora, ao se situarem numa terra alheia, ocupando-a e praticando atos possessórios, sem ao menos terem estabelecido um acordo formalizado em cartório ou verbalmente com o senhor, estar-se-ia tratando de pequenos posseiros e não de agregados. Por que o autor insistiu em reconhecê-los dessa maneira? A seguir, analisaremos algumas informações históricas colhidas naqueles processos encaminhados à Relação do Rio de Janeiro para compreendermos um pouco mais sobre as relações de propriedade formadas nas terras de José Pereira de Almeida.

Posseiros ou Agregados? A formação da fazenda cafeeira na cidade de Valença

Sem sombra de dúvida, a fazenda Casal era caracterizada por uma expressiva extensão de matas ainda incultas. Ao ser declarada nos Registros Paroquiais contendo oito sesmarias, é muito provável que o terreno não fosse totalmente aproveitado nem pelo pai, o Barão de Ubá, nem pelo filho, José Pereira de Almeida. As terras poderiam ter sido apropriadas, mas não necessariamente foram exploradas, pelo menos não por aqueles que detinham o domínio legal da propriedade. Todavia, havia uma comunidade de posseiros que vivia naquelas paragens há algum tempo. Joaquim Barbosa do Nascimento, por exemplo, avaliava ter chegado ali por volta de 1843 (12 anos antes da abertura do processo de despejo). ${ }^{14}$ Por isso, a estratégia de José Pereira de

14 AN: Fundo 84 - Relação do Rio de Janeiro. Notação do Processo: BR.AN,RIO.84.0.ACI.10135. Nome da parte 1: Joaquim Barbosa do Nascimento, Nome da parte 2: José Pereira de Almeida. Ação: Cível - Despejo. Ano do Processo: 1855. Comarca: Valença. Caixa: 556. Número: 565. Maço: 0, p. 9-9v. 
Almeida foi se aproximar deles a fim de assegurar um tranquilo relacionamento entre aqueles que já cultivavam a terra e o proprietário absenteísta que queria explorá-la tardiamente para obter lucro. No depoimento do fazendeiro Geraldo Rodrigues da Costa e Silva, extraímos o seguinte:

(...) sabe por ouvir dizer que os autores dando uma janta, e convidando quase todos os agregados na ocasião da janta, tratando a todos como filhos, lhes dizia que podiam plantar tudo quanto quisessem, e fora benfeitorias, que em nunca as correria, e que desta sorte os animou a fazer benfeitorias $(\ldots)^{15}$

A aproximação se deu mediante um jantar a convite do proprietário. ${ }^{16}$ $\mathrm{Na}$ verdade, a ocasião representou a incorporação destes posseiros à fazenda Casal, tratados agora como agregados, com liberdade para morar e cultivar nas terras da Casal com consentimento de seu senhor, José Pereira de Almeida. Ocorria uma transformação da relação de propriedade anterior, balizada pela posse da terra, em uma relação de agregação reconhecida pelo senhor.

Segundo Margarida Moura (1988), esta transformação dos direitos de propriedade revelava uma dinâmica agrária bastante comum no mundo rural brasileiro: as relações de agregação e de apossamento da terra eram, na verdade, faces de uma mesma moeda. Os termos "agregado" e "posseiro" eram intercambiados nos processos de formação da fazenda, com o posseiro sendo expropriado, e em sua fase posterior de estabilização, com o agregado sendo incorporado à fazenda (MOURA, 1988: 129-136). Ou seja, José Pereira de Almeida incorporou os posseiros às suas terras para ter mão-de-obra para

15 AN: Fundo 84 - Relação do Rio de Janeiro. Notação do Processo: BR.AN,RIO.84.0.ACI.04541. Nome da parte 1: Antônio Moreira Ferro, Nome da parte 2: José Pereira de Almeida. Ação: Cível - Despejo. Ano do Processo: 1855. Comarca: Valença. Número: 3182. Maço: 272, p. 42-45.

${ }^{16}$ Segundo Antonio Candido (1977), era comum a reunião de vizinhos e trabalhadores a fim de efetuar determinado trabalho, como a realização de derrubadas, roçadas e colheitas em matos virgens. Logo depois desta cooperação vicinal, aconteciam algumas festas com o devido oferecimento de alimentos como forma de retribuição por parte do beneficiado. No nosso caso, o jantar oferecido por José Pereira de Almeida foi uma ocasião para incorporar trabalhadores que transformassem a mata virgem em cafezal na sua fazenda nos anos seguintes e não uma cooperação horizontal entre vizinhos. Era uma festa com claras intenções proprietárias e exploratórias. 
explorar o solo virgem ali existente, com a expectativa futura de transformar a Casal numa fazenda especializada na produção comercial do café. ${ }^{17}$

Segundo Cláudia Tessari (2012: 24), o padrão de trabalho no mundo rural paulista não era "contínuo, sistemático e linear, como é o trabalho nas fábricas (...) é dependente do ciclo da vida de cada planta, do clima e da ação do clima sobre as plantas. Isso implica que ele seja um trabalho descontínuo, com tarefas e ritmos diferentes ao longo do ano agrícola". Neste ínterim, a autora desvenda uma extrema sazonalidade na demanda por mão de obra na agricultura cafeeira, condicionando momentos de mais trabalho (como nas derrubadas, no plantio e na colheita) ou menos trabalho (quando se cuidava apenas do que já havia sido plantado) e, até mesmo, momentos de vacância (quando praticamente não se trabalhava na produção comercial do café, mas sim nas outras tantas atividades realizadas nas fazendas e alhures) (TESSARI, 2012: 24-25).

A atividade de derrubada nas matas, para preparar o terreno para a produção cafeeira nos próximos anos, era uma empreitada considerada perigosa. Por este motivo, muitos fazendeiros utilizavam o trabalho livre e nacional para não arriscar sua mão-de-obra escrava nestas atividades (MUNIZ, 1979). Por este motivo, "a fazenda cafeeira necessitava, para seu funcionamento, de uma complexidade de atividades que eram muitas e contínuas, exigindo mão de obra abundante, variada e adaptada a todos os tipos de serviços." Os agregados, caipiras e caboclos seriam personagens frequentes nestes momentos, principalmente nos trabalhos de desmatamento, queima e limpeza do terreno ${ }^{18}$ (TESSARI, 2012: 71-77).

\footnotetext{
${ }^{17}$ A expansão da fronteira também é outro elemento presente no caso. A incorporação de mais terras na fronteira era uma prática recorrente para a manutenção e a reprodução das atividades cafeeiras no Vale do Paraíba fluminense, devido às práticas de cultivo e produção predatórias e extensivas. Ver, a este respeito, os trabalhos de João Fragoso (1983; 2013); Warren Dean (1977; 1996) e Ligia Osório Silva (1996; 2008).

${ }_{18}$ Além destes serviços iniciais, os agregados poderiam continuar avançando na fronteira, incorporando mais terras na vizinhança e, por ventura, proteger o patrimônio dos fazendeiros que travassem conflitos judiciais com seus vizinhos, aparecendo até como testemunhas a favor dos primeiros. No entanto, alguns agregados também poderiam peticionar terrenos nas fronteiras dizendo que se apossaram deles por conta própria. Em vista dessa dinâmica ambígua de apropriação territorial, a funcionalidade dos agregados para os senhores poderia se tornar
} 
Nos depoimentos das testemunhas, constava ter o senhor "mais de cem agregados" $"$ : um número significativo para um megaproprietário que possuía 159 escravos nesta fazenda, sendo majoritário o número daqueles cativos avaliados como roceiros (66 escravos) e carpinteiros (8 escravos), que assumiriam os serviços efetivados por estes trabalhadores livres recémincorporados à Casal depois desta preparação inicial do solo para o plantio do café. ${ }^{20}$ Contudo, os agregados foram aí bastante práticos ao se aproveitarem da relação de propriedade reconhecida pelo senhor. Segundo consta, eles construíram benfeitorias e produziram alguns gêneros, comerciais e de subsistência, estabelecendo morada habitual e ocupação produtiva; dois fatores bastante valorizados pela Lei de Terras de 1850, que legitimava posses que atendessem a estes requisitos em seu artigo $5^{\circ} .{ }^{21}$ Joaquim Barbosa do Nascimento, por exemplo, construiu uma casa de morada no valor de $40 \$ 000$ réis e plantou 11 mil pés de café que valiam 2 contos e 640 mil réis. ${ }^{22}$

Fato curioso aconteceu com os outros dois agregados que também foram alvo do processo de despejo encaminhado à segunda instância. Tanto Antônio Moreira Ferro quanto João Ferreira dos Santos alegaram que se estabeleceram no Mundo Novo depois de terem comprado as benfeitorias de outro agregado que já vivia naquela região, de nome Joaquim José dos Santos. ${ }^{23}$ Por outro lado, a historiografia reconheceu que a prática costumeira de transacionar benfeitorias feitas em terras particulares era um elemento singular que

contraproducente e perigosa, dependendo das situações em jogo. Para mais informações, ver o trabalho clássico de Márcia Motta (1998) e de Felipe de Melo Alvarenga (2019; 2020).

${ }_{19}$ AN: Processo cível de Despejo (Antônio Moreira Ferro e José Pereira de Almeida), p. 42-45.

${ }^{20}$ ETMP/IPHAN: Processo cível de Inventário (Elisa Constança de Almeida e José Pereira de Almeida), p. 65-75. Constavam, aproximadamente, 100 escravos especializados. 51 não estavam em idade produtiva (crianças, idosos, inválidos ou sem valor), 1 estava fugido há 2 anos e 7 não tinham informações sobre especialização. Isso difere muito da avaliação feita na fazenda Ubá, da qual não constava a especialização dos cativos no inventário.

${ }^{21}$ Segundo este artigo: "Art. $5^{\circ}$ Serão legitimadas as posses mansas e pacificas, adquiridas por ocupação primária, ou havidas do primeiro ocupante, que se acharem cultivadas, ou com princípio de cultura e morada habitual do respectivo posseiro, ou de quem o represente". In: BRASIL. Lei $n^{\circ} 601$, de 18 de setembro de 1850, que dispõe sobre as terras devolutas do Império.

22 AN: Processo cível de Despejo (Joaquim Barbosa do Nascimento e José Pereira de Almeida), p. $9-9 \mathrm{v}$.

${ }^{23}$ A grafia muda no decorrer dos relatos: ora aparecia José Joaquim dos Santos ora Joaquim José dos Santos. Todavia, acreditamos que se tratava da mesma pessoa. 
caracterizava a realidade dos "situados" e não a dos agregados. Uma situação era um empreendimento agrícola que se igualava aos sítios. Não se tratava de uma propriedade com título legal, mas era reconhecida pelas organizações judiciárias locais as benfeitorias construídas pelo situado em terras de outrem, estando garantida, inclusive, a possibilidade de se realizarem transações de compra e venda destas situações, à revelia do dono das terras (MATTOS, 2009). O situado "podia dispor da sua propriedade para vendê-la ou hipotecá-la sem a autorização do proprietário legal, como também a podia passar em herança." Caso chegasse a ser expulso, tinha como garantia o preço que seria pago pela sua situação. $O$ proprietário que o despejasse teria que, obrigatoriamente, indenizar as suas benfeitorias (ZENHA, 1984: 24-25).

Em nosso caso, acreditamos que os agregados desenvolveram uma autonomia que acabou aproximando-os da realidade dos situados. Antônio Moreira Ferro disse que depois de comprar a situação do agregado antecessor, continuou a plantar café e a fazer outras benfeitorias, a saber: uma casa de morada, paiol, engenho de cana, mandiocal, 11 mil e 500 pés de café, muitas árvores frutíferas e capoeiras para 10 alqueires de planta, totalizando a quantia de 4 contos de réis. ${ }^{24}$ João Ferreira dos Santos também alegou ter feito mais benfeitorias depois da compra feita a Joaquim José dos Santos, tendo como patrimônio os seguintes bens: uma casa de morada, paiol, 8 mil e 900 pés de café de 3 a 4 anos de idade, mandiocal e outras plantações que valiam, ao todo, 2 contos de réis. ${ }^{25}$

Estes bens representavam o trabalho acumulado de muitos agregados que transformavam a mata virgem em produções nada desprezíveis no interior da fazenda Casal. A construção de benfeitorias, por outro lado, abriu a possibilidade para que alguns agregados-situados as vendessem a outros pequenos lavradores que quisessem se estabelecer por ali. Foi o que aconteceu com Antônio Ferro e João dos Santos. Mas como o desenvolvimento desta

\footnotetext{
${ }^{24}$ AN: Processo cível de Despejo (Antônio Moreira Ferro e José Pereira de Almeida), p. 8-8v.

AN: Fundo 84 - Relação do Rio de Janeiro. Notação do Processo: BR.AN,RIO.84.0.ACI.04292. Nome da parte 1: João Ferreira dos Santos, Nome da parte 2: José Pereira de Almeida. Ação: Cível - Despejo. Ano do Processo: 1855. Comarca: Valença. Caixa: O. Número: 2670. Maço: 240, p. 7-7v.
} 
autonomia (com possibilidades abertas para que agregados transacionassem suas benfeitorias) pode ser explicado?

Como vimos, José Pereira de Almeida concedeu o direito para que os posseiros incorporados à Casal plantassem tudo o que quisessem. Mas parece que ele não fiscalizou os trabalhos realizados em sua fazenda, visto que as testemunhas comentaram que o proprietário nunca estava presente. Estava muito ocupado negociando na cidade e viajou por alguns anos para a Europa. A reprodução da relação de agregação no tempo era atualizada com o consentimento do administrador da fazenda Casal, José Gonçalves Portugal. A maioria das testemunhas reconheceu que os agregados estavam cultivando e plantando com a anuência dele. Francisco Gonçalves Portugal, irmão do administrador, disse, inclusive, que a transação das benfeitorias negociadas por Antônio Moreira Ferro foi consentida por seu irmão, dando-se "expressa licença" para o novo agregado construir novas benfeitorias. ${ }^{26}$

Estamos diante de um proprietário absenteísta que transferia sua autoridade de mando - sobre terras e homens - a seu administrador. Entre a ausência do senhor e a presença do administrador, os agregados aproveitavam as brechas para desenvolver ainda mais sua autonomia na Casal. ${ }^{27}$ Por outro lado, isto não quer dizer que José Gonçalves Portugal não buscasse controlar os direitos de propriedade desta comunidade de agregados: as testemunhas disseram que o administrador tentou passar "um papel de arrendamento" para que alguns agregados começassem a pagar renda, se quisessem continuar produzindo naquelas terras. Alguns indícios demonstram que a sujeição ao arrendamento foi buscada para transformar a relação de propriedade daqueles

\footnotetext{
${ }^{26}$ AN: Processo cível de Despejo (Antônio Moreira Ferro e José Pereira de Almeida), p. 21-26.

27 Alguns estudos recentes sobre escravidão demonstram que a figura do administrador e, principalmente, a do feitor de escravos, era mais um elemento que complicava o julgamento final de processos judiciais envolvendo conflitos entre senhores e escravos. Muitas das vezes, os senhores esquivavam-se de deliberações desfavoráveis para si na justiça, argumentando que foram os feitores ou administradores que tomaram as decisões equivocadas. Neste caso, isentavam-se da possível pena, individualizando a culpa na figura destes mandantes subordinados ao poder senhorial. O tripé senhor, feitor e escravo representava o entrecruzamento destes vários níveis de conflito que eram, por sua vez, visibilizados na hora que a contenda era encaminhada à justiça (LARA, 1988; MACHADO, 2014). Como estamos vendo, este tripé também era significativo para as relações construídas com homens e mulheres livres e pobres.
} 
três agregados-situados que transacionaram benfeitorias (o que vendeu e os dois que compraram). Entretanto, todos os depoimentos confirmaram que nunca foi passado o papel e a relação de arrendamento não se efetivou, pelo menos para estes três casos.

O desenvolvimento da autonomia destes posseiros transformados em agregados (por que não agregados-situados?) poderia ser uma questão espinhosa a ser resolvida pelo proprietário que quisesse afirmar seu domínio após a Lei de Terras de 1850. Aqueles agregados que se estabeleceram nas terras da fazenda Casal com o consentimento de José Pereira de Almeida poderiam reivindicá-las, ainda mais com a ocupação do terreno se tornando costumeira. Para que isso não acontecesse, o "senhor e possuidor de terras" se adiantou: abriu oito processos de despejo para expulsar algumas famílias de agregados no ano de 1855, antes de declarar sua fazenda Casal no ano de 1856. Mas, antes disso, era preciso reconhecê-los de alguma forma, definindo seus direitos de propriedade na justiça.

(...) a iniciativa de ação judicial por parte do fazendeiro que quer expulsão é, justamente, a da possessória de reintegração, argumentando que uma fração de seu direito de 'usus', de posse plena e mansa de dominium, está sendo turbada pela presença nele de uma família de 'posseiros' que insiste em morar e roçar dentro da propriedade. Por esse caminho ele deteriora a condição de agregado, traduzindo-a judicialmente por outra, a de posseiro, que não pode viver em estado de copropriedade com quem possui documentos de validade jurídica superior, que atestam a propriedade privada exclusiva. Fazendo o agregado aparecer como um intruso e turbador que deve sair, em vez de lavrador estável que tem direito de permanecer, a argumentação patronal transmuta o predicado basilar da condição de agregado - estar à disposição do fazendeiro - em alguém que sempre esteve independente daquele, ainda que favorecido pelo acesso a um lugar para morar e plantar (MOURA, 1988: 122-123).

Segundo Margarida Moura (1988), os senhores que desejavam expropriar seus agregados descontruíam as antigas relações de agregação ao afirmar que eles eram "posseiros" que estavam "invadindo" suas propriedades, 
apesar destes terem vivido ali por muitos anos. ${ }^{28}$ De outro modo, a estratégia de José Pereira de Almeida pareceu ter sido outra: ele cismou em reconhecê-los enquanto "agregados" que estavam ali sem o "consentimento" do senhorio, enquadrando sua argumentação nas provisões das Ordenações Filipinas que definiam que ninguém poderia "reter a casa alheia (...) sem o consentimento da pessoa". ${ }^{29}$ Qual o motivo para esta afirmação?

A historiografia recente constatou que pequenos posseiros podiam ter encarado os Registros Paroquiais como uma possibilidade para garantir acesso à terra, interpretando o sentido da Lei de 1850 com significados estranhos aqueles defendidos pelos grandes fazendeiros (MOTTA, 1998: 175-178). Ligia Osório Silva identificou um caso em que os posseiros no Vale do Paranapanema "registravam suas posses no Registro do Vigário com data antecipada; no caso em pauta, em vez do ano de 1856, o posseiro colocou 1847." (COBRA apud SILVA, 2008: 227). Como se sabe, só seriam revalidadas aquelas posses efetivadas antes da promulgação da Lei de Terras de 1850. Por este motivo, falsificações de títulos e declarações simuladas eram recorrentes nos livros de registros de terras em diversas localidades (DEAN, 1971: 606-625; HOLSTON, 1993: 68-89).

Mas isso não acontecia somente com pequenos posseiros. $\mathrm{O}$ apossamento também se dava por parte daqueles proprietários ou sesmeiros que procuravam estender seus limites em regiões afins, mesmo que já tenham em

\footnotetext{
28 Há que se levar em conta que a referida autora analisou diversos litígios envolvendo agregados e fazendeiros no contexto posterior ao Estatuto do Trabalhador Rural de 1963, em trabalho de campo no Vale do Jequitinhonha, Minas Gerais. Os contextos históricos são bem diferentes. Até porque, um século atrás, depois da Lei de Terras de 1850, era bastante complicado afirmar que pequenos posseiros estavam embrenhados numa fazenda. Isto porque este mesmo código legislativo garantia a legitimação daqueles atos possessórios que fossem realizados antes de 1850 . Por este motivo, era importante não tratá-los como posseiros, pois eles poderiam argumentar que estavam ali há bastante tempo, com morada habitual e princípio de cultura.

${ }^{29}$ José Pereira de Almeida expressou que "o consentimento do senhorio não foi logo provado, na forma do aviso 23 de julho de 1811, alvará de 27 de abril de 1814, parágrafo 5". In: AN: Processo cível de Despejo (Joaquim Barbosa do Nascimento e José Pereira de Almeida), p. 1010v. Este aviso remetia aos títulos 23 e 24 do $4^{\circ}$ Livro das Ordenações Filipinas com o seguinte conteúdo: "ninguém pode reter a casa alheia, nem morar nela sem o consentimento da pessoa, cuja for; e posto que o que nela mora, diga que a quer tanto por tanto, e pagar de aluguel quanto outrem por ela der; não o pode fazer sem o consentimento do senhor dela." Disponível em: <http://www1.ci.uc.pt/ihti/proj/filipinas/ordenacoes.htm>. Acesso em: 06/02/19.
} 
seu poder grandes extensões de terras (MACHADO, 1993: 34). Não foi raro o caso de sesmeiros que também eram grandes posseiros e que entravam em conflitos com seus vizinhos na hora de confirmarem seus domínios (SECRETO, 2012; ALVARENGA, 2019). Esta realidade de apossamento das terras no Brasil foi bastante complexa e dinâmica e isso ficava mais patente quando ocorria a autoidentificação de pequeno posseiro na justiça para legitimar o acesso à terra.

A figura do agregado poderia ser transmutada na figura do pequeno posseiro, que realizava atos possessórios de maneira mansa e pacífica e que poderia referendar sua ocupação produtiva com morada habitual nos Registros Paroquiais de Terras. Este esforço de mudança de identidade foi perceptível no caso da revolta dos agregados do Barão de Piabanha em Paraíba do Sul no ano de 1858, estudado por Márcia Motta (1998), que interpretou a contenda como "um processo de lutas pelo direito à terra, que permitiu a consolidação de uma comunidade de agregados que se esforçavam por se constituírem como pequenos posseiros.” (MOTTA, 1998: 211).

Portanto, reconhecer aquela comunidade de pequenos lavradores como agregados tinha o sentido claro de reforçar a submissão inerente a uma relação de dependência, o que desestruturava a possível demanda de que seriam posseiros, que sempre tiveram autonomia para cultivar e estabelecer morada naquela fazenda, o que dificultava a legitimação da posse pela Lei de 1850 . No entanto, eram agregados, mas "sem consentimento" do senhor: uma caracterização um tanto embaralhada que disfarçava a estratégia do proprietário de deslegitimar a ocupação produtiva de boa-fé de um agregado que procedeu na "invasão" de sua fazenda. O "posseiro" se transformava em "agregado", porque ele comprometeria a realização da propriedade de José Pereira de Almeida.

$\mathrm{Na}$ justiça local, o fazendeiro abriu cinco processos de despejo envolvendo os "agregados" Severino de Tal ${ }^{30}$, José Barbosa de Tal ${ }^{31}$, Camillo

\footnotetext{
${ }^{30}$ AMJERJ/CCPJ: Nome da parte 1: Jose Pereira d' Almeida, Nome da parte 2: Severino de Tal. Ação: Cível - Despejo. Ano do Processo: 1855. Comarca: Valença. Caixa: 1712/A. Cód. Item: 17086. Tombo: 016295.
} 
José da $\operatorname{Costa}^{32}$, Joaquim Fernandes ${ }^{33}$ e Antonio Romão Júnior ${ }^{34}$, acompanhados de suas respectivas esposas, por terem se introduzido em suas terras "sem o consentimento dos suplicantes", intimando-os para despejo no termo de 30 dias. Foram processos bastante céleres e objetivos, visto que os representantes das cinco famílias não compareceram à audiência pública no Juízo municipal de Valença para abertura dos termos conciliatórios. Ou seja, só tivemos acesso à denúncia do proprietário que conseguiu despejá-los à sua revelia no mesmo ano da abertura destes cinco processos, finalizados no dia 27 de agosto de 1855. Entretanto, estes agregados tiveram direito a suas benfeitorias construídas. A terra não era mais deles, mas o fruto de seu trabalho foi garantido; administrando o fracasso, poderiam se estabelecer em outras localidades.

Esta prática proprietária de José Pereira de Almeida foi uma forma de salvaguardar o domínio sobre suas fazendas. $\mathrm{O}$ fato de ter expulsado as cinco famílias na justiça local em meados de 1855 , antes de declarar a fazenda Casal em 1856, foi um cálculo racional bastante preciso, no intuito de resolver "pendências" em suas terras e garantir, finalmente, o significado da expressão que deu abertura ao processo judicial, a saber: afirmar-se como "senhor e possuidor de diversas fazendas neste município".

Esta conclusão também foi identificada no trabalho de Márcia Motta (1998) sobre os conflitos agrários oitocentistas em Paraíba do Sul. Segundo a autora,

É de se supor, no entanto, que alguns [fazendeiros] se sentissem mais inclinados a registrar suas terras em decorrência de conflitos ocorridos perto de suas fazendas.

\footnotetext{
${ }^{31}$ AMJERJ/CCPJ: Nome da parte 1: Jose Pereira d' Almeida, Nome da parte 2: José Barbosa de Tal. Ação: Cível - Despejo. Ano do Processo: 1855. Comarca: Valença. Caixa: 1712/A. Cód. Item: 17087. Tombo: 016296.

${ }^{32}$ AMJERJ/CCPJ: Nome da parte 1: Jose Pereira d' Almeida, Nome da parte 2: Camillo José da Costa. Ação: Cível - Despejo. Ano do Processo: 1855. Comarca: Valença. Caixa: 1712/A. Cód. Item: 17088. Tombo: 016297.

33 AMJERJ/CCPJ: Nome da parte 1: Jose Pereira D'almeida, Nome da parte 2: Joaquim Fernandes. Ação: Cível - Despejo. Ano do Processo: 1855. Comarca: Valença. Caixa: 1707/A. Cód. Item: 17036. Tombo: 016245.

34 AMJERJ/CCPJ: Nome da parte 1: Jose Pereira D'almeidae, Nome da parte 2: Antonio Romão Júnior. Ação: Cível - Despejo. Ano do Processo: 1855. Comarca: Valença. Caixa: 1443/D. Código: 14443. RG: 13652.
} 
Assim, alguns talvez se mostrassem mais dispostos a se submeter à determinação legal, na expectativa de que isto viesse a garantir o seu domínio, potencialmente ameaçado pela presença de invasores, como foram os casos dos fazendeiros [de Paraíba do Sul] que haviam aberto processos de embargo, entre 1850 e 1857. Dos nove autores dos processos, sete registraram suas terras no Registro Paroquial. Outros, porém, podiam não considerar importante o ato de registrar suas terras. Talvez porque naquele momento não estivesse ocorrendo nenhum tipo de contestação ao seu domínio. Talvez porque entendessem que registrar a terra significava limitar seu poder, submetendo-se ao governo (não diferente, aliás, da atitude dos sesmeiros, cuja maioria jamais limitou e demarcou a sua terra) (MOTTA, 1998: 168-169).

Logo, a declaração da fazenda Casal nos Registros Paroquiais foi uma estratégia proprietária compartilhada com outros fazendeiros do Vale do Paraíba na década de 1850: José Pereira de Almeida declarou estas terras no município de Valença porque elas estavam sendo alvo de um domínio que estava sendo contestado pela autonomia conquistada por aquela comunidade de agregados estabelecidos com a sua anuência. Muitos puderam ter sido expulsos dali sem o auxílio da justiça: provavelmente foram expropriados à força sem terem direito, ao menos, as suas benfeitorias.

O suor de seu trabalho foi incorporado à fazenda Casal que era, por sua vez, valorizada com as produções daqueles que um dia tocaram diariamente suas vidas por ali. As dezenas de milhares de pés de café declarados no inventário de 1864 foram, na verdade, plantados por esses agregados. A expropriação de muitos mascarava a apropriação do trabalho alheio acumulado na fazenda. O lucro advindo desta expulsão compensava o pagamento da indenização de alguns poucos que peticionaram por seus direitos na justiça.

De maneira ambígua, a estratégia inicial branda de incorporar, cordialmente, aquela comunidade de posseiros à fazenda foi transformada em violência senhorial materializada na expropriação, alguns anos depois. O processo de formação da fazenda cafeeira demandava, na verdade, este contínuo movimento de transformação de direitos de propriedade que ora eram protegidos quando convinha ao proprietário e ora eram desprotegidos quando a 
autonomia conquistada pelos agregados perturbava a realização de alguns projetos senhoriais.

Formalizando projetos senhoriais: os contratos de parceria e as "pendências agregadas" na propriedade cafeeira

Um dos projetos de José Pereira de Almeida foi identificado na correspondência feita entre ele e o seu primo de segundo-grau, Joaquim Ribeiro de Avellar, mais conhecido por seu título de Visconde de Ubá (MUAZE, 2008). ${ }^{35}$ Nesta correspondência, José Pereira de Almeida detalhou as diretrizes de um contrato de parceria que efetivou com alguns imigrantes europeus para trabalharem na fazenda Casal, por volta da década de $1860 .{ }^{36} \mathrm{Na}$ avaliação dos bens de 1864, identificamos que o fazendeiro já possuía "nove lances de casas na colônia" avaliadas em 1:080\$000 réis. ${ }^{37}$

Depois de ter resolvido as "pendências" com os agregados, o proprietário decidiu embarcar na construção de novas relações de propriedade e de trabalho em sua fazenda. Dessa vez arriscou na incorporação de trabalhadores vindos do outro lado do Atlântico na condição de parceiros, seguindo o caminho trilhado pelos fazendeiros paulistas, como Nicolau Vergueiro, que já havia se adiantado nesta empreitada ainda na década de 1840 (DEAN, 1977; DAVATZ, 1980).

Nos artigos do contrato de parceria, José Pereira de Almeida estabelecia uma relação de trabalho com duração de três anos, contabilizados desde o dia da chegada dos europeus ao Rio de Janeiro. Ele se obrigava a custear a passagem da vinda e o transporte deles até a sua fazenda. O salário no primeiro ano valeria $4 \$ 000$ réis mensais (incluídas aquelas passagens pagas), no segundo ano $14 \$ 000$ réis e no terceiro $16 \$ 000$ réis. Doaria algumas mudas de roupa no

${ }^{35}$ Para mais informações genealógicas sobre estas famílias, ver o sítio eletrônico Family Search. Disponível em: <https://www.familysearch.org/tree/pedigree/landscape/LBPV-Q9X>. Acesso em: 09/11/18.

${ }^{36}$ AN: Fundo 05 - Fazenda Pau-Grande, 1771-1941 (Digitalizado). Notação: 833. 9. Flash 3: Série 3 - Visconde de Ubá. Subsérie 4 - Pessoal. Microfilmagem: 1995-1996, p. 833.1-833.9 ou pdf. 1235-1238.

${ }^{37}$ ETMP/IPHAN: Processo cível de Inventário (Elisa Constança de Almeida e José Pereira de Almeida), p. 66-76v. 
verão e no inverno e sustentaria os trabalhadores a base de feijão, arroz com toucinho, angu e broa de milho, adicionados de carnes ou peixes no jantar, a escolha do parceiro. Obrigava-se a tratar de suas enfermidades na enfermaria existente na fazenda Casal, sem que os salários deles fossem descontados no tempo em que estivessem doentes.

Por seu turno, o parceiro deveria trabalhar em todos "aqueles serviços de lavoura que lhe forem designados por José Pereira de Almeida ou a pessoa que fizer suas vezes." Durante a colheita de café, cada parceiro teria o número de alqueires fixos para colher por dia, recebendo uma gratificação de 100 réis a cada alqueire que fosse colhido a mais. Teriam direito a um pedaço de terra que poderiam cultivar somente nos domingos e nos dias santos, visto que nos dias de semana teriam que trabalhar para o proprietário, com horários regulados para o descanso do almoço e da janta. A colônia localizava-se num lugar apartado da sede da Casal, trabalhando "sempre separados dos escravos da fazenda, com os quais eles não deverão ter contato algum." Caso quisessem romper com o contrato antes do tempo considerado, era estipulado o pagamento da passagem que foi custeada pelo proprietário e mais uma multa por cada ano ainda não trabalhado. $^{38}$

Interpretamos que José Pereira de Almeida buscava, na verdade, substituir a mão-de-obra livre nacional que foi expulsa com estes novos contratos de parceria efetivados com os trabalhadores europeus. É curioso notar que esta substituição só ocorreu depois que aquela comunidade de agregados foi despejada. Isto representou uma estratégia bastante calculada pelo proprietário: os parceiros recém-introduzidos na Casal cultivariam naquelas preciosas matas virgens já transformadas em plantações de café com o suor do trabalho dos antigos posseiros-agregados. Além disso, a vantagem destes novos contratos de parceria era que o proprietário não corria o risco de ter que litigar na justiça pela posse da terra, como aconteceu no caso dos agregados. A desconstrução dos direitos de propriedade destes trabalhadores nacionais foi

\footnotetext{
${ }^{38}$ AN: Fundo 05 - Fazenda Pau-Grande, 1771-1941 (Digitalizado). Notação: 833. 9. Flash 3: Série 3 - Visconde de Ubá. Subsérie 4 - Pessoal. Microfilmagem: 1995-1996, p. 833.1-833.9 ou pdf. 1235-1238.
} 
acompanhada da construção de novos direitos à terra concedidos a estes parceiros imigrantes: uma "troca" que rescindia os contratos orais e informais antes estabelecidos pelos agregados e que formalizaria novos contratos escritos com parceiros que teriam acesso direto, mas limitado à terra.

A parceria foi uma relação de trabalho utilizada pelos fazendeiros como uma alternativa à tão evocada crise da mão-de-obra escrava e apareceu timidamente disseminada na cidade de Valença a partir da década de 1870 , embora o escravismo continuasse sendo hegemônico neste município até o final da década de 1880 (ALMEIDA, 1994: 160). O contrato de parceria foi se configurando como uma nova forma de sujeição encontrada pelos senhores para extrair o sobretrabalho deste imigrante, coagido a labutar na plantation cafeeira em situações análogas à exploração do braço cativo. Conjugando experiências com o trabalho escravo e livre, muitos fazendeiros superpunham a figura do senhor sobre a do patrão (ALMEIDA, 1994: 181-195; 245-249; SLENES, 1997), no afã de postergarem a crise da escravidão, por um lastro de tempo mais folgado, de controlarem a mão-de-obra a qualquer custo e de potencializarem seus interesses econômicos (CHALHOUB, 2012; MAMIGONIAN, 2017).

Os contratos de parceria foram bastante disseminados na região cafeeira paulista, principalmente na segunda metade do século XIX. Algumas análises historiográficas identificaram os diversos percalços e as principais mudanças dos contratos estabelecidos entre os trabalhadores do café e os fazendeiros paulistas antes e depois da promulgação da Lei de Locação de Serviços de 1879, que buscaria regularizar as relações firmadas entre as duas partes (STOLCKE; HALL, 1983; STOLCKE, 1986; LAMOUNIER, 1988; GRINBERG, 2008). A despeito do colonato ter sido a relação de trabalho hegemônica na "transição do trabalho escravo para o livre" em São Paulo, alguns trabalhos recentes nuançaram esta solução, comprovando a persistência dos contratos de parceria e a permanência do trabalho sazonal efetivado por nacionais antes mesmo da emergência do trabalhador volante da década de 1960 (FALEIROS, 2007; TESSARI, 2012). 
Os contratos de parceria no Vale do Paraíba fluminense também foram percebidos pela historiografia, mas não foram hegemônicos e estruturantes das relações de trabalho nas fazendas, pelo menos durante as décadas de 1850 a 1870. Nos anos anteriores a 1888 e no imediato pós-abolição, a parceria seria amplamente disseminada, tanto para o caso do Rio de Janeiro como nos casos da Zona da Mata mineira e do Estado do Espírito Santo, como forma de retenção dos libertos e dos imigrantes nas fazendas cafeeiras para manter a produção comercial por mais alguns anos (SANTOS, 1984; LANNA, 1985; SALETTO, 1985; 1996; RIOS, 1990; 2001; MATTOS, 2013; MATTOS; RIOS, 2005; 2007). Neste ínterim, o caso da fazenda de José Pereira de Almeida configuraria um caso exemplar no quadro fluminense esboçado pela historiografia, visto que ali a parceria foi institucionalizada ainda durante a vigência do escravismo na segunda metade do século XIX.

Diferentemente dos agregados, os parceiros tinham o contrato como instrumento de defesa de seus direitos de propriedade. ${ }^{39}$ Segundo Gelsom Rozentino de Almeida, que analisou alguns processos judiciais ocorridos em outras colônias de trabalhadores europeus criadas em Valença e Cantagalo,

\begin{abstract}
Através de 'brechas' nas cláusulas contratuais, o colono podia, com amparo técnico, interpretar a seu favor a própria legislação em vigor, como uma forma de reação. Contudo, ele não escapava ao sistema, visto ser necessário que ele se empregasse em outro estabelecimento, o que significava um contato prévio e alguém que se dispusesse a pagar a sua dívida e da sua família. Mesmo contestando a sua condição e reagindo à opressão do fazendeiro, o imigrante acaba por tornar-se refém das normas vigentes, podendo melhorar a sua situação, mudando de local e de empregador, mas não conseguia mudar as regras, nem a exploração que era vítima (ALMEIDA, 1994: 176).
\end{abstract}

Neste sentido, os parceiros eram personagens que apareciam na justiça para reivindicarem seus direitos de propriedade, mobilizando as cláusulas do contrato estabelecido com os patrões e confrontando o exercício do poder senhorial quando acreditavam que sua autonomia e liberdade estavam sendo

39 Infelizmente, não encontramos nenhum vestígio empírico que nos aproximasse do relacionamento laboral entre José Pereira de Almeida e seus novos trabalhadores contratados. Por este motivo, a análise sobre a parceria que se segue foi baseada em literatura secundária. 
limitadas. Entretanto, o contrato de parceria especificava um tempo de trabalho na unidade de produção. Isto comprometia a reprodução do modo de vida de muitos imigrantes. Até porque, segundo a historiografia, foram poucos os imigrantes que conseguiram comprar terras com o salário recebido em troca dos serviços prestados aos fazendeiros do Sudeste cafeeiro. ${ }^{40}$ A regra no Vale do Paraíba fluminense foi o crescente endividamento das famílias de imigrantes europeus, que mal conseguiam reproduzir seu modo de vida, como constatou Gelsom Rozentino (1994) em sua pesquisa.

Entrementes, entre a desconstrução e construção de novos direitos de propriedade na fazenda Casal, parece que os agregados que lá viveram continuavam impondo alguns limites aos projetos proprietários de José Pereira de Almeida. Se aquelas cinco famílias de agregados foram expulsas no juízo municipal em 1855, este não parece ter sido o destino daqueles três agregados que encaminharam suas causas à segunda instância, na Relação do Rio de Janeiro. O caso deles durou até inícios da década de 1870, momento em que o senhor já havia realizado esta substituição da mão-de-obra livre em sua fazenda. Aconteceu que José Pereira de Almeida não pagou as benfeitorias destes três agregados, atitude diferenciada no que tange àquelas cinco famílias que tiveram direito à indenização, julgada na primeira instância em 1855 .

Estes bens estavam retidos na mão de Paulo Gomes Ribeiro de Avellar, depositário das benfeitorias e aparentado de José Pereira de Almeida.

\footnotetext{
${ }^{40} \mathrm{Na}$ Província do Espírito Santo, por exemplo, a historiografia comprovou uma realidade interessante: "ali, ao contrário do que diz a historiografia, o café se mostrou viável em pequenas propriedades apoiadas basicamente no trabalho familiar." (CELIN, 1984; 1985, p. 68). Segundo Vilma Almada (1984), a região do Itapemirim, ao sul da província do Espírito Santo, até conheceu a realidade da grande plantation escravista e cafeeira, tocada por fazendeiros que vinham de outras regiões e que traziam seus escravos para ali se estabelecerem no movimento de expansão das fronteiras cafeeiras ao longo do século XIX. Entretanto, a realidade da província capixaba na virada do século XIX para o século XX era composta por um contingente expressivo de estrangeiros que se estabeleceram nos pequenos lotes doados pelo governo, onde a média era a de 50 a 75 hectares de terras por famílias, principalmente compostas por italianos e alemães (CELIN, 1984; 1985). Além disso, Saletto $(1985 ; 1996)$ comprovou um importante processo de fracionamento das grandes propriedades cafeeiras, nas quais muitos proprietários vendiam lotes de terras a pequenos proprietários e parceiros. A persistência de alguns latifúndios no século $\mathrm{XX}$, no entanto, não anulava a importância destas pequenas propriedades produtoras de café no Estado capixaba. Sobre o processo de formação social desta camada de pequenos proprietários e a sua relação com a política de "colonização" do Império ao Sul do país ver, principalmente, o trabalho de Paulo Pinheiro Machado (1999).
} 
Possivelmente, o proprietário não as pagou por acreditar que elas eram bastante valiosas: além das casas de morada e das plantações de gêneros alimentícios, totalizavam-se 23.400 pés de café avaliados nos processos. E isto contando somente as produções destes três agregados que litigaram na justiça. Quantas benfeitorias e pés de café foram cultivados a mais no lugar denominado Mundo Novo por outras dezenas de agregados que não foram, sequer, indenizados?

Enquanto mais contratos de parceria eram realizados no decorrer das décadas de 1860 e 1870, José Pereira de Almeida tinha que lidar com o passado das relações de propriedade em sua fazenda. As "pendências" que foram supostamente resolvidas antes de declarar a Casal nos Registros Paroquiais de Terras continuavam dificultando seus planos: seu projeto para o futuro deveria acertar contas com o passado de ocupação produtiva de uma comunidade de agregados que insistia em lutar por suas benfeitorias.

Entre vai-e-vens, embargos e contra-embargos, a decisão tomada pela justiça foi um tanto contraditória: o proprietário até foi julgado no sentido de indenizar as benfeitorias; mas os agregados foram obrigados a pagar "a importância dos danos causados com as roçadas e derrubadas" que fizeram a mando do próprio senhor! $!^{41}$ Aliás, a justiça avaliou que Antônio Moreira Ferro $^{42}$ e João Ferreira dos Santos ${ }^{43}$ deveriam desembolsar também "a renda que os réus deveriam pagar anualmente ao proprietário da fazenda, conforme o uso do país", numa clara tentativa de enquadrá-los em uma relação de arrendamento que nunca existiu.

O advogado de defesa, José Pedro de Figueiredo Carvalho, indignado com a decisão da justiça, afirmou o seguinte:

Os réus apelantes recorrendo para este Egrégio Tribunal, e pedindo reforma da sentença de $1^{\mathrm{a}}$ instância que os condenou a pagar indenização pela ocupação das terras, e por dano causado com derrubadas e roçadas, esperam que lhes será feita justiça. A ocupação das terras com consentimento dos

\footnotetext{
${ }^{41}$ AN: Processo cível de Despejo (Joaquim Barbosa do Nascimento e José Pereira de Almeida), p. 71-75.

42 AN: Processo cível de Despejo (Antônio Moreira Ferro e José Pereira de Almeida), p. 66v68.

${ }^{43}$ AN: Processo cível de Despejo (João Ferreira dos Santos e José Pereira de Almeida), p. 6970v.
} 
senhorios, como se evidencia pela leitura dos autos, não lhes dá o direito de reclamar dinheiro a título de arrendamento, desde que tal coisa não foi determinada por um contrato, e pelo contrário é estilo e uso constante dos nossos fazendeiros consentirem a indivíduos, que são conhecidos pelo nome de agregados, o rotearem as suas terras sem outro ônus além de serem obrigados a todo o tempo a entregarem as terras, mas precedendo sempre a competente indenização, sendo raro, senão fato virgem, o de conservar agregados até o momento em que as colheitas vão começar, para assim locupletar-se o rico com o suor do pobre (...). Como condenar os apelantes a pagar indenização pelas derrubadas e roçadas que fizeram, quando para fazer plantações não há outro meio senão pôr o mato abaixo, e quando está provado dos autos que a ocupação era com consentimento do senhorio? Tão desarrazoada nos parece tal fundamento, que acreditamos será o Venerando Acórdão reformado, com o que aliás se fará a costumada. ${ }^{44}$

A culpabilização dos agregados pelos "danos" causados nas matas virgens da fazenda (LOURENÇO, 2001: 163-177) e a aparição de um contrato de arrendamento que nunca existiu sinalizavam o caráter senhorial da deliberação da justiça, comandada por indivíduos que auxiliavam os interesses dos grandes Barões do Café. No final da contenda, foi feito um acórdão com estes três e logo depois foi julgada a desistência dos embargos anteriormente lavrados, concluindo-se o processo judicial somente no ano de 1873.

Os resultados e os percalços: crise senhorial e o definhamento do complexo cafeeiro

José Pereira de Almeida faleceu no ano seguinte, em 1874, sendo aberto um inventário para a partilha dos seus bens. ${ }^{45}$ Não podemos saber ao certo se as benfeitorias foram realmente pagas aos agregados. No entanto, podemos avaliar se a transição da mão-de-obra livre planejada por ele deu certo, além de identificar quais foram as consequências mais aparentes no que tange a

\footnotetext{
${ }^{44}$ Idem, p. 144-144v.

${ }^{45}$ ETMP/IPHAN: Nome da parte 1: José Pereira de Almeida (Inventariado), Nome da parte 2: Maria Júlia de Aguiar Almeida (Inventariante). Ação: Cível - Inventário. Ano do Processo: 1874-1884. Comarca: Vassouras. Notação do Processo: 103664176001.
} 
preservação de seu patrimônio, com as onerosas despesas decorrentes desta contínua transformação de direitos de propriedade em suas fazendas.

Na segunda avaliação da fazenda Casal em 1870, percebemos que José Pereira de Almeida insistia em preservar a mão-de-obra escrava em suas fazendas ao mesmo tempo em que assinava novos contratos de parceria com os imigrantes europeus. Constavam 182 escravos estimados no total de 151:850\$000 réis, número um pouco maior em relação aos 159 escravos avaliados em 1864. Além dos escravos, os nove lances de casas na colônia continuavam existindo na Casal, valorizados agora na quantia de 1:300\$000 réis. Isto sem contar com a expressiva escravaria de sua fazenda-sede, a Ubá, que contava com, aproximadamente, 215 escravos nesta segunda avaliação. Este aumento da escravaria foi explicado pelo remanejamento dos cativos que trabalhavam na fazenda Salvaterra, aquela fazenda-abastecedora localizada no município de Niterói, e que se encontrava em "estado estacionário" por volta de 1870, segundo a avaliação do próprio José Pereira de Almeida. ${ }^{46}$

A insistência deste megaproprietário em trazer parceiros europeus até a sua fazenda Casal e a preservação da mão-de-obra escrava, concentrada nas fazendas Ubá e Casal, indicam que ele não queria que a produção cafeeira em suas fazendas perdesse a potência econômica de outrora. Esta busca incessante pela abastança também foi identificada quando José Pereira de Almeida decidiu comprar várias propriedades urbanas em Petrópolis para continuar ostentando sua riqueza. Esta era outra estratégia senhorial utilizada para perpetuar aqueles sinais marcadores de diferenciação social no final do Oitocentos, mesmo que a produção rural estivesse entrando em decadência. ${ }^{47}$

Estas aquisições ocorreram depois da morte de sua primeira esposa em 1864. Alguns anos depois, José Pereira de Almeida casou-se novamente, dessa vez com a dona Maria Júlia de Aguiar Almeida, tendo com ela quatro filhas. O luxo representado pelas mobílias e joias antes constantes na fazenda Ubá foi

\footnotetext{
${ }^{46}$ ETMP/IPHAN: Processo cível de Inventário (Elisa Constança de Almeida e José Pereira de Almeida), p. 85-100v, p. 128-138; p. 162-162v.

47 ETMP/IPHAN: Processo cível de Inventário (José Pereira de Almeida e Maria Júlia de Aguiar Almeida), p. 63v-71v; p. 237-254v.
} 
deslocado para as propriedades adquiridas na cidade imperial de Petrópolis; a propósito, um ótimo lugar para estreitar laços com o círculo social da nobreza brasileira e com a própria família imperial (MUAZE, 2008).

Não obstante, parece que esta estratégia senhorial não surtiu o efeito desejado. $\mathrm{O}$ fazendeiro estava passando por dificuldades financeiras. Não foi à toa que em 14 de junho de 1872 foi assinado uma escritura de reconhecimento de dívida com o Banco do Brasil na quantia de 415:128\$295 réis, na qual o senhor se obrigava a pagá-la, caso não quisesse perder a fazenda Ubá, sede de sua família, que foi hipotecada pelo banco. ${ }^{48}$ Enquanto não fosse quitada a dívida, não se poderia proceder à partilha dos bens aos herdeiros neste segundo inventário aberto em 1874.

Provavelmente, o fazendeiro não pagou as benfeitorias daqueles agregados, pelo menos até o ano de 1873, porque a situação financeira de sua família estava em risco. Isto é, José Pereira de Almeida não conseguiu realizar com sucesso a transição da mão-de-obra livre em sua fazenda: endividado, não conseguia nem pagar as benfeitorias daqueles três agregados que levaram suas causas à segunda instância. Quanto mais indenizar todas as outras benfeitorias construídas por aquela comunidade de agregados incorporados à fazenda Casal entre 1840 a 1850.

Em 1874, ele faleceu. E, curiosamente, identificamos que a fazenda Casal não foi avaliada neste segundo inventário aberto na justiça. Uma hipótese para esta ausência pode ser formulada com a partilha dos bens constantes no inventário da primeira esposa deste fazendeiro, dona Elisa Constança de Almeida. Os herdeiros dos bens da falecida foram seus dois filhos: o mais velho, João Rodrigues Pereira de Almeida, e o mais novo, Joaquim Pereira de Almeida. Em acordo com o próprio José Pereira de Almeida, o filho maior adquiriu os bens rurais da família em Valença; já Joaquim Pereira de Almeida

\footnotetext{
48 ETMP/IPHAN: Processo cível de Inventário (José Pereira de Almeida e Maria Júlia de
} Aguiar Almeida), p. 112-120v. 
ficou com as casas e propriedades urbanas da Corte do Rio de Janeiro, porque eram "os bens que sofreram pouca alteração em preço". 49

Entretanto, em 1877, João Rodrigues Pereira de Almeida vendeu os bens que herdou ao doutor Josué Torres de Albuquerque. ${ }^{50}$ Alguns anos depois, em 1881, foi a vez de Joaquim Pereira de Almeida, que vendeu sua herança a Antônio José de Araújo Viana. ${ }^{51}$ Com estas transações, acreditamos que a fazenda Casal e algumas propriedades urbanas na Corte do Rio de Janeiro foram transpassadas a terceiros: elas não constavam no inventário do pai porque foram desfeitas pelos irmãos, preocupados com a pesada dívida contraída com o Banco do Brasil. Não foi à toa que Joaquim Pereira de Almeida reiterou em seu testamento o seguinte: "declaro que nada devo, em lugar algum, a quem quer que seja por qualquer título ou forma, portanto deve ser considerada falsa qualquer dívida que por hipótese apareça."52

Estrategicamente, os herdeiros mais velhos jogaram a carga onerosa na família construída ao redor da segunda esposa de José Pereira de Almeida. Maria Júlia de Oliveira, suas filhas e seu novo marido, Augusto Coelho de Oliveira, "são obrigados ao pagamento da dívida pública" e não eles. ${ }^{53}$ Esta segunda família, por sua vez, lançou mão de vários estratagemas para contornar a difícil situação financeira: tentaram arrendar os prédios da Estação de Ubá em 1881 por $420 \$ 000$ réis mensais ${ }^{54}$; e demarcaram, novamente, a fazenda Ubá para tentar aliená-la mediante arrematação em praça pública, proposta que foi inclusive noticiada numa tiragem do Jornal do Commercio no final de $1883 .{ }^{55}$

\footnotetext{
${ }^{49}$ ETMP/IPHAN: Processo cível de Inventário (Elisa Constança de Almeida e José Pereira de Almeida), p. 164.

${ }^{50}$ ETMP/IPHAN: Nome da parte 1: Herdeiros de José Pereira de Almeida, Nome da parte 2: Joaquim Candido Guimarães Júnior. Ação: Cível - Libelo. Ano do Processo: 1886. Comarca: Vassouras. Notação do Processo: 103664336006, p. 35-36.

${ }^{51}$ ETMP/IPHAN: Processo cível de Inventário (José Pereira de Almeida e Maria Júlia de Aguiar Almeida), p. 350-352v.

52 APTJERJ/DEGEA: Nome da parte 1: Joaquim Pereira de Almeida. Ação: Cível Testamento. Ano do Processo: 1893. Comarca: Petrópolis (Juízo da Provedoria - $3^{\circ}$ Ofício). Caixa: 01.576.478-3, p. 2-7.

${ }^{53}$ ETMP/IPHAN: Processo cível de Libelo (Herdeiros de José Pereira de Almeida e Joaquim Candido Guimarães Júnior), p. 35-36; p. 93-93v.

${ }^{54}$ ETMP/IPHAN: Processo cível de Inventário (José Pereira de Almeida e Maria Júlia de Aguiar Almeida), p. 355.

${ }^{55}$ Idem, p. 537v-547v; p. 688-689; p. 956-961; p. 980-981.
} 
Apesar destes subterfúgios, o Banco do Brasil sequestrou todos os bens da fazenda Ubá entre 1885 a 1890, alegando que não foram pagos 267:966\$820 réis. ${ }^{56}$ A sede do grande patrimônio rural da família Pereira de Almeida foi apropriada pelo Banco por conta da dívida que não foi quitada no tempo devido. ${ }^{57}$ Alguns herdeiros ainda teimaram em exportar alguma produção de café e retiveram algumas benfeitorias alegando que foram construídas depois da escritura de hipoteca de 1872. Outros vão continuar negociando um rateio para o levantamento do sequestro hipotecário de alguns poucos bens. ${ }^{58}$

A decadência da família se tornava uma realidade cada vez mais presente. Não foi à toa que identificamos que o filho mais novo, Joaquim Pereira de Almeida, que possuía uma pequena fortuna de apenas quatro casas na Corte do Rio de Janeiro, cometeu suicídio com um tiro de revólver no ano de 1893, numa viagem de costume que fazia da cidade de Petrópolis para retornar a sua residência na capital federal. ${ }^{59} \mathrm{O}$ suicídio representava a falência financeira da família; aliás, uma das mais importantes do Vale do Paraíba naquele contexto histórico.

Portanto, a formação e a estabilização de uma fazenda cafeeira no Vale do Paraíba fluminense nesta segunda metade do Oitocentos tinha um pouco disso: a abastança aparente, conquistada pelo suor do trabalho dos "encostados", era bastante efêmera. Na verdade, a fortuna provinda da produção do café no Vale "foi uma riqueza fugaz" que durou pouco mais de 70 anos (MUNIZ, 2005: 239-241). Assim como aconteceu com os herdeiros de

\footnotetext{
${ }^{56}$ ETMP/IPHAN: Nome da parte 1: Herdeiros de José Pereira de Almeida, Nome da parte 2: Banco do Brasil. Ação: Cível - Sequestro de Bens. Ano do Processo: 1885. Comarca: Vassouras. Notação do Processo: 102663861018.

${ }^{57}$ ETMP/IPHAN: Nome da parte 1: Herdeiros de José Pereira de Almeida, Nome da parte 2: Banco do Brasil. Ação: Cível - Execução (Executivo Hipotecário). Ano do Processo: 1890. Comarca: Vassouras. Notação do Processo: 102663926003.

${ }^{58}$ Ver, por exemplo: ETMP/IPHAN: Nome da parte 1: Thomas Alves Júnior, Nome da parte 2: Banco do Brasil (Exequente), Nome da parte 3: Herdeiros de José Pereira de Almeida (Executados). Ação: Cível - Requerimento (Levantamento de Depósito). Ano do Processo: 1891. Comarca: Vassouras. Notação do Processo: 104664631073 e ETMP/IPHAN: Nome da parte 1: Augusto Coelho de Oliveira, Nome da parte 2: Herdeiros de José Pereira de Almeida. Ação: Cível - Requerimento. Ano do Processo: 1892. Comarca: Vassouras. Notação do Processo: 104664611085.

59 APTJERJ/DEGEA: Processo cível de Testamento (Joaquim Pereira de Almeida), p. 2-4; p. $5 \mathrm{v}-6$.
} 
José Pereira de Almeida, muitas outras grandes fazendas foram perdidas aos bancos ou leiloadas na virada do século XIX e início do século XX (FRAGOSO, 2013: 167-180).

Em nosso caso, esta crise rápida esteve relacionada com a aposta na preservação da escravidão nos últimos anos do Oitocentos, conjugada com a insistência em estabelecer relações de parceria com imigrantes europeus, após uma violenta transformação dos direitos de propriedade da mão-de-obra livre nacional que foi despejada à sua revelia, muitos sem direito à indenização de suas benfeitorias. Aliado a estes fatores ligados às relações de produção, a crise financeira do fazendeiro foi alimentada pela reprodução onerosa de um modo de vida luxuoso, que prezava pela demarcação das diferenças de qualidade social entre os homens livres naquela sociedade oitocentista (MATTOS, 2013). Esta estratégia senhorial produziu uma dívida que não foi quitada: o resultado desta transformação dos direitos de propriedade foi o sequestro da fazenda Ubá ao Banco do Brasil entre 1885 a 1890. Eis a outra face da lua desta "transição da mão-de-obra escrava para a livre" tão comentada pela historiografia brasileira (COSTA, 1998).

\section{Considerações Finais}

Neste artigo, foi possível analisar o processo de formação e de estabilização da propriedade cafeeira na cidade de Valença a partir dos conflitos com os agregados que moravam e trabalhavam dentro das fazendas dos Barões do Café. Pudemos avaliar que, a despeito de não possuírem o título, estes indivíduos lutavam por seus direitos de propriedade para garantir a reprodução material de sua existência dentro daquele espaço no qual era exercido o poder senhorial.

Nos conflitos aqui analisados, a dinâmica revelou uma disputa bastante desigual, envolvendo processos de dominação social verticalizados, mas confrontados com o desenvolvimento da autonomia dos subordinados. Os "encostados" que Manoel Eloy dos Santos Andrade evocou em suas memórias 
foram, na verdade, atores históricos significativos que tinham planos e projetos diferentes em relação aos dos grandes proprietários no Vale do Café. Eles também foram personagens que dificultaram a realização da propriedade cafeeira (CONGOST, 2007), principalmente depois da promulgação da Lei de Terras de 1850.

Vimos que o aproveitamento da mão-de-obra dos agregados foi de suma importância para que o senhor preparasse o terreno para dar início ao cultivo de café em sua fazenda. Uma comunidade de posseiros - estranhos à família senhorial - foi incorporada à propriedade cafeeira na condição de agregados porque era do interesse do senhor aproveitar-se do trabalho alheio. Não obstante, esta comunidade de agregados conquistou uma autonomia nada desprezível com a morada que lhes foi concedida naquela fazenda: construíram benfeitorias e plantaram dezenas de milhares de pés de café, valorizando aquelas terras. Alguns até venderam suas situações a outros que decidiram se agregar por ali. De qualquer forma, o senhor decidiu despejá-los, logo depois que sua fazenda já contava com extensos cafezais. Para substituir aquela força de trabalho, assinou diversos contratos de parceria com imigrantes europeus que trabalhariam em suas fazendas escravistas. Não obstante, os agregados continuaram peticionando pela indenização de suas benfeitorias na justiça, até porque elas representavam o suor de seu trabalho acumulado na fazenda.

Concluímos que a propriedade cafeeira valenciana foi o resultado de um contínuo processo de transformação de direitos de propriedade: as relações com a propriedade da terra eram constantemente construídas e desconstruídas, protegidas e desprotegidas ao longo do tempo (PEDROZA, 2016), principalmente na segunda metade do século XIX, quando os senhores decidiram explorar, de maneira conjunta, o trabalho escravo e o trabalho livre para tocar suas fazendas de café. No entanto, nem tudo acontecia como os fazendeiros planejavam. Os agregados também "transformaram-se" para desenvolver sua autonomia e para lutar pelos seus direitos à terra.

Em razão disso, se só nos prendêssemos nas declarações de terras dos Barões do Café nos anos 1854-1857, não captaríamos a lógica destes conflitos 
agrários "miúdos" que se reproduziram ao longo da segunda metade do Oitocentos. Como forma de descongelar a objetividade destes registros, acompanhamos os processos cíveis e criminais que nos deram a oportunidade de avaliar o que estava acontecendo dentro destas fazendas que foram declaradas depois da Lei. A criação deste novo sistema normativo, portanto, permitiu a construção de variadas estratégias que modificavam constantemente a realidade. A norma teve que lidar com formas costumeiras de acesso à terra mobilizadas por estes agregados que tentavam alargar seus espaços de autonomia (LEVI, 2000). Usavam a lei a seu próprio favor e não seria o título de alguém que os intimidaria caso tivessem que contornar situações de despejo.

Por este motivo, é sempre importante ressaltar que as relações de propriedade, ao serem relações sociais, devem ser observadas desde uma pluralidade de ângulos, focalizando a mutabilidade dos direitos sobre terras para além dos princípios legais e dos marcos institucionais (CONGOST, 2007). Esta perspectiva relacional abre novas questões sobre o problema, visto que muitas disputas reduzidas à definição genérica de "conflitos fundiários" poderiam ser conectadas a litígios centrados em relações sociais propriamente ditas. Isto pode contribuir com outras vertentes para o entendimento da aplicação da Lei de Terras no Brasil do século XIX.

\section{Referências}

ALMADA, V. P. F. de. Escravismo e Transição: O Espírito Santo (1850-1888). Rio de Janeiro: Edições Graal, 1984.

ALMEIDA, G. R. de. Hoje é dia de Branco. O trabalho livre na Província Fluminense: Valença e Cantagalo, 1870-1888. 285 fls. Dissertação (Mestrado em História) - Universidade Federal Fluminense, Niterói, 1994.

ALVARENGA, F. de M. De Terras Indígenas à Princesa da Serra Fluminense: o processo de realização da propriedade cafeeira em Valença (Província do Rio de Janeiro, Século XIX). Jundiaí [SP]: Paco Editorial, 2019.

ALVARENGA, F. de M. O agregado na fazenda do café: estratégias de fixação e de mobilidade de homens livres e pobres em Valença (Província do Rio de Janeiro, 1850-1888). Revista Cantareira (UFF), Niterói, v. 32, s/n, 2020, p. 121-136. 
ANDRADE, M. E. dos S. O Vale do Paraíba. Rio de Janeiro: Real Gráfica, 1989.

AZEVEDO, C. M. M. de. Onda Negra, Medo Branco: o Negro no Imaginário das Elites, Século XIX. São Paulo: Annablume, 2004.

BOURDIEU, P. As estruturas sociais da economia. Lisboa: Instituto Piaget, 2001.

CANDIDO, A. Os Parceiros do Rio Bonito: estudo sobre o caipira paulista e a transformação dos seus meios de vida. $4^{a}$ edição. São Paulo: Livraria Duas Cidades, 1977.

CELIN, J. L. Migração europeia, expansão cafeeira e o nascimento da pequena propriedade no Espírito Santo. 330 fls. Dissertação (Mestrado em Economia) - Universidade Federal do Rio Grande do Sul, Porto Alegre, 1984.

CELIN, J. L. Contribuição ao estudo da pequena produção na cafeicultura brasileira: o caso do Espírito Santo. Análise Econômica, Porto Alegre, v. 2, n. 4, 1985, p. 67-75.

CHALHOUB, S. Machado de Assis, historiador. São Paulo: Companhia das Letras, 2003.

CHALHOUB, S. A força da escravidão: ilegalidade e costume no Brasil oitocentista. São Paulo: Companhia das Letras, 2012.

CONGOST, R. Tierras, Leyes, Historia: estudios sobre la gran obra de la propiedad. Barcelona: Crítica, 2007.

COSTA, E. V. da. Da Senzala à Colônia. São Paulo: Fundação Editora da UNESP, 1998.

DAVATZ, T. Memórias de um colono no Brasil (1850). São Paulo: Editora Itatiaia, 1980.

DEAN, W. Latifundia and Land Policy in Nineteenth-Century Brazil. The Hispanic American Review, v. 51, n. 4, 1971, p. 606-625.

DEAN, W. Rio Claro: Um Sistema Brasileiro de Grande Lavoura, 1820-1920. Rio de Janeiro: Paz e Terra, 1977.

DEAN, W. A Ferro e Fogo. A História e a Devastação da Mata Atlântica Brasileira. São Paulo: Companhia das Letras, 1996. 
FALEIROS, R. N. Fronteiras do Café: fazendeiros e "colonos" no interior paulista (1917-1937). 445 fls. Tese (Doutorado em Economia) - Universidade Estadual de Campinas, Campinas, 2007.

FRAGOSO, J. L. R. Sistemas Agrários em Paraíba do Sul (1850-1920): um estudo de relações não-capitalistas de produção. 197 fls. Dissertação (Mestrado em História) - Universidade Federal do Rio de Janeiro, Rio de Janeiro, 1983.

FRAGOSO, J. L. R. Homens de Grossa Aventura: Acumulação e Hierarquia na Praça Mercantil do Rio de Janeiro (1790-1830). Rio de Janeiro: Civilização Brasileira, 1998.

FRAGOSO, J. L. R. Barões do Café e sistema agrário escravista. Paraíba do Sul / Rio de Janeiro (1830-1888). $1^{a}$ edição. Rio de Janeiro: 7 Letras, 2013.

FRANCO, M. S. de C. Homens Livres na Ordem Escravocrata. $4^{a}$ edição. São Paulo: Fundação Editora da Unesp, 1997.

FREIRE, J. Escravidão e Família Escrava na Zona da Mata Mineira Oitocentista. São Paulo: Alameda, 2014.

GENOVESE, E. D. A Terra Prometida: O Mundo que os Escravos Criaram. Rio de Janeiro: Paz e Terra, 1988.

GRINBERG, K. Código Civil e Cidadania. $3^{\text {a }}$ edição. Rio de Janeiro: Jorge Zahar Editor, 2008.

HOLSTON, J. Legalizando o ilegal: propriedade e usurpação no Brasil. Revista Brasileira de Ciências Sociais, São Paulo, v. 8, n. 21, p. 68-89, fev. 1993.

LAMOUNIER, M. L. Da Escravidão ao Trabalho Livre: a Lei de Locação de Serviços de 1879. Campinas: Papirus, 1988.

LANNA, A. L. D. A transformação do trabalho: a passagem para o trabalho livre na Zona da Mata Mineira (1870-1920). 168 fls. Dissertação (Mestrado em História) - Universidade Estadual de Campinas, Campinas, 1985.

LARA, S. H. Campos da Violência: escravos e senhores na Capitania do Rio de Janeiro, 1750-1808. Rio de Janeiro: Paz e Terra, 1988.

LEMOS, M. S. O Índio Virou Pó de Café? Resistência indígena frente à expansão cafeeira no Vale do Paraíba. Jundiaí: Paco Editorial, 2016.

LEVI, G. Sobre a Micro-História. In: BURKE, P. (Org.). A Escrita da História: novas perspectivas. São Paulo: Editora da Unesp, 1992, p. 133-161. 
LEVI, G. A Herança Imaterial. Trajetória de um exorcista no Piemonte do século XVII. Rio de Janeiro: Civilização Brasileira, 2000.

LOURENÇO, F. A. Agricultura Ilustrada: liberalismo e escravismo nas origens da questão agrária brasileira. Campinas: Editora da Unicamp, 2001.

MACHADO, H. F. Escravos, Senhores e Café: A crise da cafeicultura escravista do Vale do Paraíba Fluminense, 1860-1888. Niterói: Editora Cromos/Clube de Literatura, 1993.

MACHADO, M. H. P. T. Crime e Escravidão: Trabalho, Luta e Resistência nas Lavouras Paulistas (1830-1888). São Paulo: Editora da Universidade de São Paulo, 2014.

MACHADO, M. M. Entre Fronteiras: posses e terras indígenas nos sertões (Rio de Janeiro, 1790-1824). (Coleção Terra). Guarapuava: Unicentro, 2012.

MACHADO, P. P. A política de colonização do Império. Porto Alegre: Editora da UFRGS, 1999.

MAMIGONIAN, B. Africanos Livres: a abolição do tráfico de escravos no Brasil. São Paulo: Companhia das Letras, 2017.

MARQUESE, R.; TOMICH, D. O Vale do Paraíba escravista e a formação do mercado mundial do café no século XIX. In: GRINBERG, K.; SALLES, R. $O$ Brasil Imperial: Volume II - 1831-1870. Rio de Janeiro: Civilização Brasileira, 2009, p. 369-370.

MATTOS, H. Ao Sul da História: lavradores pobres na crise do trabalho escravo. Rio de Janeiro: Editora da FGV, Faperj, 2009.

MATTOS, H. Das cores do silêncio: os significados da liberdade no Sudeste escravista - Brasil, século XIX. Edição revista. Campinas: Editora da Unicamp, 2013.

MELlO E SOUZA, L. de. Desclassificados do ouro: a pobreza mineira no século XVIII. 4a edição. Rio de Janeiro: Edições Graal, 2004.

MESSIAS, R. C. O cultivo do café nas bocas do sertão paulista: mercado interno e mão de obra no período de transição (1830-1888). São Paulo: Editora da Unesp, 2003.

MOTTA, M. M. M. Pelas “Bandas D'Além”: Fronteira Fechada e Arrendatários-Escravistas em uma Região Policultora - 1808-1888. 198 fls. Dissertação (Mestrado em História) - Universidade Federal Fluminense, Niterói, 1989. 
MOTTA, M. M. M. Nas Fronteiras do Poder: conflito e direito à terra no Brasil do século XIX. Rio de Janeiro: Vício de Leitura, 1998.

MOURA, M. M. Os Deserdados da Terra: a lógica costumeira e judicial dos processos de expulsão e invasão da terra camponesa no sertão de Minas Gerais. Rio de Janeiro: Bertrand Brasil, 1988.

MUAZE, M. As Memórias da Viscondessa: Família e Poder no Brasil Império. Rio de Janeiro: Jorge Zahar Editor, 2008.

MUNIZ, C. M. L. Os Donos da Terra: um estudo sobre a estrutura fundiária do Vale do Paraíba Fluminense no século XIX. 184 fls. Dissertação (Mestrado em História) - Universidade Federal Fluminense, Niterói, 1979.

MUNIZ, C. M. L. A Riqueza Fugaz: trajetórias e estratégias de famílias de proprietários de terras de Vassouras, 1820-1890. 260 fls. Tese (Doutorado em História) - Universidade Federal do Rio de Janeiro, Rio de Janeiro, 2005.

NAXARA, M. R. C. Estrangeiro em sua própria terra: representações do brasileiro (1870-1920). São Paulo: Annablume, 1998.

PEDROZA, M. da S. Engenhocas da Moral: redes de parentela, transmissão de terras e direitos de propriedade na freguesia de Campo Grande (Rio de Janeiro, século XIX). Rio de Janeiro: Arquivo Nacional, 2011.

PEDROZA, M. da S. Desafios para a História dos Direitos de Propriedade da Terra no Brasil. Revista Em Perspectiva [On Line], Fortaleza, v. 2, n. 1, p. 7-33, 2016.

PESSOA, T. C. O Império da Escravidão: o complexo Breves no Vale do Café (Rio de Janeiro, c. 1850 - c. 1888). Rio de Janeiro: Arquivo Nacional, 2018.

RIOS, A. M. L. Família e Transição: Famílias Negras em Paraíba do Sul, 1872-1920. 135 fls. Dissertação (Mestrado em História) - Universidade Federal Fluminense, Niterói, 1990.

RIOS, A. M. L. My Mother Was a Slave, But Not Me: Black Peasantry and Local Politics in Southeast Brazil, c. 1870-c. 1940. 240 fls. Tese (Doutorado em História) - Universidade de Minnesota, Minnesota, 2001.

RIOS, A. M. L.; MATTOS, H. M. Memórias do cativeiro: família, trabalho e cidadania no pós-abolição. Rio de Janeiro: Civilização Brasileira, 2005.

RIOS, A. M. L.; MATTOS, H. M. Para além das senzalas: campesinato, política e trabalho rural no Rio de Janeiro pós-Abolição. In: CUNHA, O. M. G. da; GOMES, F. dos S. (Org.). Quase-Cidadão: histórias e antropologias da pósemancipação no Brasil. Rio de Janeiro: Editora da FGV, 2007, p. 55-78. 
SALETTO, N. Considerações sobre a transição do trabalho escravo ao trabalho livre na economia cafeeira do Espírito Santo (1888-1929). 155 fls. Dissertação (Mestrado em História) - Universidade Federal do Rio de Janeiro, Rio de Janeiro, 1985.

SALETTO, N. Trabalhadores Nacionais e Imigrantes no Mercado de Trabalho do Espírito Santo (1888-1930). Vitória: Editora da UFES, 1996.

SALLES, R. E o Vale era o escravo: Vassouras, século XIX. Senhores e escravos no coração do Império. Rio de Janeiro: Civilização Brasileira, 2008.

SAMARA, E. de M. "O Papel do Agregado na Região de Itu - 1780-1830". Coleção do Museu Paulista (Série de História), v. 6, São Paulo, p. 10-121, 1977.

SAMARA, E. de M. Lavoura Canavieira, Trabalho Livre e Cotidiano: Itu, 1780-1830. São Paulo: Editora da Universidade de São Paulo, 2005.

SANTOS, A. M. dos. Agricultural Reform and the Idea of Decadence in the State of Rio de Janeiro (1870-1910). 360 fls. Tese (Doutorado em Filosofia) Universidade do Texas, Austin, 1984.

SECRETO, M. V. Fronteiras em Movimento: História Comparada - Argentina e Brasil no século XIX. Rio de Janeiro, Niterói: Editora da UFF, 2012.

SILVA, E. Barões e Escravidão: três gerações de fazendeiros e a crise da estrutura escravista. Rio de Janeiro: Nova Fronteira; Brasília: INL, 1984.

SILVA, F. C. T. da. Camponeses e Criadores na Formação Social da Miséria: Porto da Folha no Sertão do São Francisco (1820-1920). 256 fls. Dissertação (Mestrado em História) - Universidade Federal Fluminense, Niterói, 1981.

SILVA, L. M. O. A Apropriação Territorial na Primeira República. In: SILVA, S.; SZMRECSÁNYI, T. (Org.). História Econômica da Primeira República. São Paulo: Editora Hucitec, 1996, p. 157-169.

SILVA, L. M. O. Terras Devolutas e Latifúndio: Efeitos da Lei de 1850. Campinas: Editora da Unicamp, 2008.

SLENES, R. W. Senhores e Subalternos no Oeste Paulista. In: ALENCASTRO, L. F. de (Org.). História da Vida Privada no Brasil. Império: a corte e a modernidade nacional. Vol. 2. São Paulo: Companhia das Letras, 1997, p. 233290.

STEIN, S. J. Vassouras: um município brasileiro do café, 1850-1900. Rio de Janeiro: Nova Fronteira, 1990. 
STOLCKE, V. Cafeicultura: homens, mulheres e capital (1850-1980). São Paulo: Editora Brasiliense, 1986.

STOLCKE, V.; HALL, M. A introdução do trabalho livre nas fazendas de café de São Paulo. Revista Brasileira de História, São Paulo, v. 3, n. 6, p. 80-120, set. 1983 .

TESSARI, C. A. Braços para a colheita: sazonalidade e permanência do trabalho temporário na agricultura paulista (1890-1915). São Paulo: Alameda, 2012.

THOMPSON, E. P. A miséria da teoria ou um planetário de erros. Uma crítica ao pensamento de Althusser. Rio de Janeiro: Zahar Editores, 1981.

THOMPSON, E. P. Costumes em Comum: Estudos sobre a Cultura Popular Tradicional. São Paulo: Companhia das Letras, 1998.

ZENHA, C. As Práticas da Justiça no Cotidiano da Pobreza: Um estudo sobre o amor, o trabalho e a riqueza através dos processos penais. 268 fls. Dissertação (Mestrado em História) - Universidade Federal Fluminense, Niterói, 1984.

Recebido em: 4 de dezembro de 2019

Aceito em: 4 de maio de 2020 